\title{
Statistical Analysis on the Impact of Nigerian Immigrants on the Economy of Ghana
}

\author{
Akologba David Akutam, Gu Jianya \\ School of Sciences \\ Zhejiang University of Science \& Technology, Hangzhou PR. CN.
}

\begin{abstract}
Ghana has been a destination for immigration in the post-colonial era and is still today hence the detrimental and potential contributions made by immigrants are worthy of investigation and examination. The country's nonenforced immigration laws have often made it a place for its neighbors to enter and work. Nigeria, a neighbor of Ghana breeds more developmental challenges than Ghana hence the movement of its citizens to Ghana for jobs and other purposes. Preferably, they move to Ghana because of the many cultural similarities and English as the official languages of the two countries. The research employs a mixed-method approach, as the subject cannot be addressed by just using either a qualitative or a quantitative method. The Study analyzes the contribution of Nigerian immigrants with multiple linear regression models and examines the relationship between Labor Market, Public Finance, and Real GDP. The Pearson's correlation coefficient was used to test the correlation between each independent variable and dependent variables. To find out Nigerian immigrant contribution to the economy of Ghana, labor Market, and Public Finance were measured against the dependent variable Real GDP in the multiple linear regression models. The results showed that there was no positive relationship between the independent variables (Labor Market and Public Finance and the dependent variable Real GDP). This implies Nigerian immigrants do not contribute to the Real GDP of Ghana.
\end{abstract}

Keywords: Immigration, Economy, Real GDP, Labor

DOI: $10.7176 / \mathrm{JESD} / 12-8-07$

Publication date: April $30^{\text {th }} 2021$

\section{Introduction}

Daily more people move to countries other than the one in which they were born. In 2019, the number of migrants universally reached an estimated 272 million, 51 million more than in 2010. International migrants comprise 3.5 percent of the global population. Equated to 2.8 percent in 2000 and 2.3 percent in 1980, the proportion of international migrants worldwide has also risen. The broader African continent and sub-West African region have historically been a 'walked-across land. This is because the migration of people within and across borders has traditionally been an integral part of society's social organization within the sub-region (Rain, 1999; Adepoju, 2005). The arrival of Colonialists' contributed to the evolution of colonial mercantilism, cities, and towns' growth in colonial territories. Thus, cities like Lagos, Dakar, Accra, Ibadan, and Lome became critical economic hubs, political and administrative power centers, and social change. The economic potentials that came with these cities' growth served to attract a host of labor migrants from different parts within the sub-region (Anarfi et al., 2003; Konseiga, 2005). The phenomenon today is no different as more and more Africans move to other African countries (Adepoju, 2010). After Ghana became the first independent country in the region in 1957, many Nigerians began moving to Ghana. They moved to Ghana preferably because of the many similar cultural similarities and English being the official languages of the two countries. It is estimated that about 1 million Nigerians live in Ghana. In light of this, the study sought to analyze the impact of Nigerian immigrants on the economy of Ghana. The study focuses on the contribution of immigrants to labor markets, public finance, and real GDP.

\subsection{Overview of Ghana's economy}

After the crushing of Ghana's economy in the early 1980s declining per capita income several years in a row, and Economic Reform Program (ERP) was introduced in 1983 with the help of the International Monetary Fund (Hutchful, 2002). These programs included improvements in the mining sector, the cocoa sector, and the sale of non-performing state corporations. All these actions and reforms were geared toward opening up Ghana's economy to investors and international trade. This was achieved partly by creating a policy and legal regime that encouraged the migration of foreign expertise and capital into Ghana, and transforming Ghana's economy from a relatively closed, trade-protected one to a more open, market-driven one (Killick, 2008). Furthermore, the introduction of practical reforms in the agriculture sector of Ghana pushed the economy to grow up steadily. Ghana has since become a strong economic performer and GDP per capita has doubled in the past 30 years. The country's GDP per capita surpasses that of its neighbors excluding Nigeria, which has the largest economy in West Africa. In 2011, Ghana achieved its highest economic growth of $15.0 \%$ as the result of the discovery of oil from the Jubilee oil field and the high prices of its primary-commodity export in the international market. In 2018, Ghana's Real 
GDP growth was $6.3 \%$ and steadily increased to $6.5 \%$ in 2019 . Ghana's current account remained stable at $3.1 \%$ of GDP in 2019, the same level as 2018.

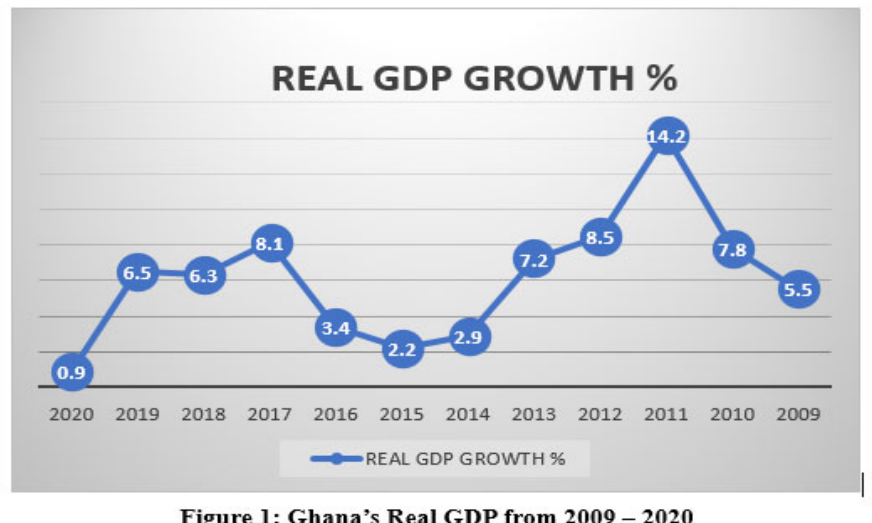

\subsubsection{General Objective}

The main objective of this research was to provide analysis on the statistical impact of Nigerian Immigrants on the Economy of Ghana.

\subsubsection{Specific Objectives}

a. To examine Nigerian Immigrant's contribution to the Labor Market and Real GDP of Ghana

b. To examine Nigerian Immigrant' contribution to Public Finance and Real GDP of Ghana.

\subsection{LITERATURE REVIEW}

There is a general lack of research on Africans moving from their country to another African country as more consideration has been given to Africans to Europe migration and related remittance flow to their countries of origin. Meanwhile, new evidence indicates that Africans moving to other African countries is about the same volume as the Africans moving to Europe migration (OECD, 2013) or even higher (Adepoju, 2010). The most related literature to this study is that the OECD/ILO (2018), How Immigrants Contribute to Ghana's Economy. The research focused on three dimensions: labor markets, economic growth, and public finance. Using the regression model, the research showed that, immigrant's direct net fiscal contribution exceeds the contribution of their native-born counterparts, irrespective of the cost scenario considered. The study also advanced that the contribution of immigrants to the government's fiscal balance exceeds the contribution of the native-born population (on a per capita basis) in Ghana. Kwabena Asante (2017) also analyzed trading activities, contributions, and integration of Nigerian traders in Ghana. The qualitative study indicated that push and pull factors are responsible for the migration of Nigerians into Ghana. The study also opined that; although the traders pose competition to Ghanaian traders within the same sector, they contribute to employment creation and offer a variety of options to the Ghanaian consumer.

\subsection{Immigrant contribution to the Labor market, Public finance, and Real Gross Domestic Product}

According to the OECD (2018), the estimated net direct fiscal impact of immigrants in the countries studied was sometimes positive, sometimes negative, and small overall. In the countries where the difference between the percapita net fiscal impacts of foreign- and native-born individuals was largest, the difference would typically be less pronounced if their average ages were equal. With a few exceptions, an equalization of the employment-topopulation ratio would have the same results.Card (2005) evaluated the local labor market approach and concludes that neither demand shocks, intercity trade nor out-migration of natives is responsible for the none existing impact of immigration in local labor markets. His study further argued, that even in the time series approaches of Borjas, the effect of immigration should be modest. Lewis (2003), Ottaviano, and Peri (2005) also found no negative or even a positive effect on native wages and employment as a result of immigration, Also, Pettinger, 2019 posited that net inflows of people also lead to an increase in aggregate demand. Migrants will increase the total spending within an economy as well as increasing the supply of labor; there will be an increase in the demand for labor relating to the increased spending within the economy. Ceteris paribus, net migration should lead to an increase in real Gross Domestic Product.

\subsection{Nigerians in Ghana}

Like any other country on the African continent, Nigeria has its migration history summarized in political, cultural, and historical experiences (Adepoju and van der Wiel, 2010). The total population of Nigeria is estimated at 200.963,599 million people, being the largest population within the ECOWAS and Africa overall (World Bank, 2019). Nigerians form the highest number of international and West African migrants in Ghana than any other nationals (Twum-Baah, 2005). Studies have shown that Nigerians were migrating to Ghana as far back as the early 
nineteenth century even though they were already transacting business during the era of the caravan trade (AntwiBosiako 2011; Awumbila et al 2009). Nigerians are found in all of the regions undertaking a wide range of activities from trading, manufacturing, banking, media, construction, agriculture, and of course the largest number being students, represented at all levels of the educational ladder ( Kwabena Asante, 2017).

\subsection{Regression Model}

The earliest form of regression was the method of least squares (French: méthode des moindres carrés), which was published by Legendre in 1805, and by Gauss in 1809. Legendre and Gauss both applied the method to the problem of determining, from astronomical observations; the orbits of bodies about the Sun. Gauss published a further development of the theory of least squares in 1821, including a version of the Gauss-Markov theorem. Different forms have been deducted from the regression model over the years. The study used multiple linear regressions, also known simply as multiple regressions. It is the type of regression that uses several explanatory variables to predict the outcome of a response variable. Multiple linear regression endeavors to model the relationship between two or more explanatory variables and a response variable by fitting a linear equation to observed data. Every value of the independent variable $x$ is associated with a value of the dependent variable $y$. The study employed multiple linear regression models, to analyze the relationship between Labor Market, Public Finance, and Real GDP. To test the correlation between each independent variable and the dependent variable, Pearson's correlation coefficient was used. Labor Market and Public Finance were measured against the dependent variable Real GDP in the multiple linear regression models.

\subsection{Pearson's Correlation Coefficient}

The Pearson's correlation coefficient was developed by Karl Pearson from a related idea introduced by Francis Galton in the 1880s, and for which the mathematical formula was derived and published by Auguste Bravais in 1844. The naming of the coefficient is thus an example of Stigler's Law. Pearson's correlation coefficient is the covariance of the two variables divided by the product of their standard deviations.

\subsection{Conceptual Framework}

Kombo and Tromp, (2009), define conceptual framework as a set of wide-ranging ideologies adopted from relevant areas of inquiry and used to organize a subsequent presentation. For this study, Regression Analysis Model was adopted to investigate the Statistical analysis on the impact of Nigerian immigrants on the economy of Ghana.

Independent variable

Dependent variable

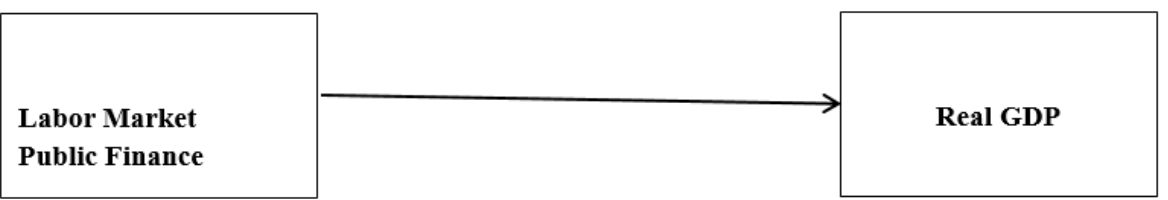

Figure 2: Independent and dependent variables

\subsection{METHODOLOGY}

The research used the mixed-method approach, as the subject could not only be addressed by qualitative and quantitative designs. In using a mixed-method, the researcher aims at presenting a comprehensive analysis of the research problem (Teye 2012; Lopez-fernandez et al, 2011; Creswell, 2009). The study employed both primary and secondary data for this research. The primary data was captured using questionnaires and secondary data was obtained from annual reports published from 2015-2019 by the Ghana statistical service. The data were analyzed by using descriptive and inferential statistical techniques using Statistical Package for Social Sciences (SPSS). Due to the increasing number of Nigerians in Ghana, it was imperative to use the simple random sampling technique, as the study could not have served every single Nigerian in Ghana a questionnaire. The population of the study consisted of 127 respondents, 92 being male and 35 being female. For the data to be valid, the targeted sources of information were obtained from mostly businesspersons and entrepreneurs who were actively living and working in Ghana. The collated data from questionnaires were used to measure their contribution to the labor force, public finance, and real GDP. To achieve this objective, multiple linear regression models were used. Tables were used for the qualitative presentation of information and a Pearson correlation coefficient was carried out to find out the relationship between the dependent variable Real GDP and the independent variables Labor Market and Public Finance. The equation of multiple linear regression models as follows:

$\mathbf{Y}=\boldsymbol{\beta}_{0}+\boldsymbol{\beta}_{1} \mathbf{X}_{1}+\boldsymbol{\beta}_{2} \mathbf{X}_{2}+\varepsilon$

Where, Y the dependent variable (Real GDP), was determined for Labor Market and Public Finance

Therefore, the equation was summarized as follow; 
REAL GDP $=\beta 0+\beta_{1} L B+\beta_{2} P F_{i t}+\varepsilon$

Where;

$\begin{array}{lr}\text { REAL GDP } & \text { Real GDP } \\ \text { B0 } & \text { the constant to be estimated by the model } \\ \beta_{1, \ldots 3} & \text { Coefficients of the independent variables } \\ \text { LB } & \text { Labor Market } \\ \text { PF } & \text { Public Finance } \\ \text { i } & 1,2,3 \ldots \ldots \ldots \ldots . .12 \\ \boldsymbol{\varepsilon} & \text { inherent error in the model }\end{array}$

4.0. ANALYSIS AND INTERPRETATION OF DATA

4.1 Immigrant Demographic characteristics and contribution to Ghana's economy Table 1Immigrant Demographic characteristics and contribution to Ghana's economy

\begin{tabular}{|c|c|c|c|c|c|c|c|}
\hline Variable & Description & Frequency & Percent & Variable & Description & Frequency & Percent \\
\hline \multirow[t]{4}{*}{ Gender } & Male & 92 & 72 & \multirow[t]{4}{*}{ Age } & Below 25 & 14 & 11 \\
\hline & \multirow[t]{3}{*}{ Female } & \multirow[t]{3}{*}{35} & \multirow[t]{3}{*}{28} & & 26-39 & 106 & 84 \\
\hline & & & & & $40-55$ & 4 & 3 \\
\hline & & & & & Above 55 & 3 & 2 \\
\hline \multirow{2}{*}{$\begin{array}{l}\text { Do Nigerian } \\
\text { Immigrants }\end{array}$} & Strongly Disagree & 4 & 3.1 & \multirow{3}{*}{$\begin{array}{l}\text { Do employed } \\
\text { Nigerian } \\
\text { immigrants }\end{array}$} & Strongly & 1 & 0.78 \\
\hline & Neutra1 & 9 & 7.0 & & disagree & 58 & 46 \\
\hline \multirow{3}{*}{$\begin{array}{l}\text { get more } \\
\text { employed } \\
\text { than }\end{array}$} & Agree & 29 & 22.7 & & Disagree & 13 & 10 \\
\hline & Strongly agree & 64 & 50.0 & \multirow{2}{*}{$\begin{array}{l}\text { get more } \\
\text { wages than }\end{array}$} & Neutral & 42 & 33 \\
\hline & & 21 & 16.4 & & Agree & 13 & 10 \\
\hline \multicolumn{2}{|l|}{ Ghanaians } & & & Ghanaians & \multicolumn{2}{|l|}{ Strongly agree } & \\
\hline \multirow{5}{*}{$\begin{array}{l}\text { Do Nigerian } \\
\text { immigrants } \\
\text { work in } \\
\text { industries }\end{array}$} & Strongly disagree & 61 & 47.7 & \multirow{5}{*}{$\begin{array}{l}\text { Do Nigerian } \\
\text { immigrants } \\
\text { participate } \\
\text { in trade and } \\
\text { other } \\
\text { services }\end{array}$} & Strongly disagree & 4 & 3.1 \\
\hline & Disagree & 8 & 6.3 & & Disagree & 28 & 21.9 \\
\hline & Neutral & 0 & 32.8 & & Neutral & 19 & 14.8 \\
\hline & Agree & 42 & 12.5 & & Agree & 68 & 53.1 \\
\hline & Strongly agree & 16 & 99.2 & & Strongly agree & 8 & 6.3 \\
\hline Do & No & 70 & 54.7 & \multirow{5}{*}{$\begin{array}{l}\text { Do Nigerian } \\
\text { immigrants } \\
\text { participate } \\
\text { in } \\
\text { agriculture }\end{array}$} & No & 62 & 48.4 \\
\hline \multirow{4}{*}{$\begin{array}{l}\text { Nigerian } \\
\text { immigrants } \\
\text { pay taxes }\end{array}$} & Maybe & 18 & 14.1 & & Maybe & 43 & 33.6 \\
\hline & Yes & 39 & 30.5 & & Yes & 22 & 17.2 \\
\hline & & & & & & & \\
\hline & & & & & & & \\
\hline
\end{tabular}

The above figure shows a representation of the demographic characteristics and some questions employed by the study to examine respondent's contribution to the economy of Ghana. From the 127 questionnaires, it was observed that $92 \%$ of the respondents were males and $35 \%$ were females. The study also showed, $84 \%$ were between $26-35$ years whereas, $11 \%, 3 \%$, and $2 \%$, were between below 25 years, $40-55$ years, and above 55 years respectively. This restates findings of other study's that posited that immigration is predominant amongst the youth of any given country. Furthermore, $50 \%$ of respondents agreed that Nigerians are more employed than Ghanaians are, $23 \%$ had a neutral opinion, and the remaining strongly agreeing or disagreeing as shown in the figure above.

In addition, results from Nigerian immigrant's participation in trade and other services showed the majority of respondents agreeing to the phenomenon. $55 \%$ of respondents indicated no when asked if Nigerian immigrants paid taxes, $30 \%$ agreed they paid taxes whereas $15 \%$ were neutral with their answers.

These results show that although Nigerian immigrants own and run businesses in Ghana, their taxes are rather insignificant and thus have a minimal impact on the Real GDP of the country. Ghana's economy is agrarian and as such, a questionnaire on Nigerian immigrant's participation in agriculture was imperious to soliciting their contribution to economic growth. $48 \%$ of respondents indicated Nigerian immigrants did not participate in agriculture whereas $17 \%$ thought otherwise and $36 \%$ gave neutral responses. These findings are in line with that of Asante(2017) which postulated that Nigerian immigrants are mostly in the urban cities thus are most likely to go into business and trading.

\subsubsection{Gross domestic product and real gross domestic product: Gross Domestic Product (GDP)}

Gross domestic product or GDP is a measure of the size and health of a country's economy over a period of time (usually one quarter or one year). It is also used to compare the size of different economies at different points in time.

$\mathbf{G D P}=\mathbf{C}+\mathbf{G}+\mathbf{I}+\mathbf{N X}$ 
(Where $\mathrm{C}=$ consumption; $\mathrm{G}=$ government spending; $\mathrm{I}=$ Investment; and $\mathrm{NX}=$ net exports)

\subsubsection{Real Gross Domestic Product (GDP)}

On the other hand, Real gross domestic product $(G D P)$ is an inflation-adjusted measure that reflects the value of all goods and services produced by an economy in a given year (expressed in base-year prices) and is often referred to as constant-price $G D P$, inflation-corrected GDP, or constant dollar GDP. Real GDP is given by Nominal GDP divided by the Deflator

$R=N / D$.

\subsection{Pearson Correlation Matrix}

A Pearson correlation coefficient was carried out to find out the relationship between the dependent variable Real GDP and the independent variables Labor Market and Public Finance.

Table 1: Pearson correlation

\begin{tabular}{|l|l|r|}
\hline \multicolumn{2}{|c|}{ Correlations } \\
\hline \multirow{2}{*}{ REAL_GDP } & Pearson Correlation & \multicolumn{1}{|c|}{ REAL_GDP } \\
\cline { 2 - 4 } & Sig. (2-tailed) & 127 \\
\cline { 2 - 4 } & $\mathrm{N}$ & .001 \\
\hline \multirow{3}{*}{ LABOR_MARKET } & Pearson Correlation & .994 \\
\cline { 2 - 4 } & Sig. (2-tailed) & 127 \\
\cline { 2 - 4 } & N & -.002 \\
\hline \multirow{3}{*}{ PUBLIC_FINANCE } & Pearson Correlation & .983 \\
\cline { 2 - 4 } & Sig. (2-tailed) & 127 \\
\cline { 2 - 4 } & N & \\
\hline
\end{tabular}

The results from Pearson's Correlation indicated that there is a weak positive correlation between Real GDP and the Labor Market and a P-Value of 0.994. While Public Finance and Real GDP had a weak negative correlation and the P-value of 0.983 . The P-values of the values were greater than the level of significance 0.05 ; this implied that there was no significant correlation among the variables under study.

\subsection{Regression Analysis}

To determine the relationship between the predictor variables Labor Market and Public Finance and the dependent variables Real GDP, a Regression analysis was run.

Table 2: Regression Analysis

\begin{tabular}{|l|l|l|l|}
\hline \multicolumn{4}{|c|}{ Variables Entered/Removed } \\
\hline Model & \multicolumn{1}{|c|}{ Variables Entered } & Variables Removed & Method \\
\hline 1 & $\begin{array}{l}\text { LABOR_MARKET, } \\
\text { PUBLIC_FINANCE' }\end{array}$ & & Enter \\
\hline a. Dependent Variable: REAL_GDP & \\
\hline \multicolumn{2}{|l}{ b. All requested variables entered. } \\
\hline
\end{tabular}

Table 3: Summary of Model

\begin{tabular}{|c|c|c|c|c|c|c|c|c|c|}
\hline \multicolumn{10}{|c|}{ Model Summary } \\
\hline \multirow[b]{2}{*}{ Mode1 } & \multirow[b]{2}{*}{$\mathrm{R}$} & \multirow[b]{2}{*}{$\begin{array}{c}\mathrm{R} \\
\text { Square }\end{array}$} & \multirow[b]{2}{*}{$\begin{array}{c}\text { Adjusted R } \\
\text { Square }\end{array}$} & \multirow[b]{2}{*}{$\begin{array}{c}\text { Std. An error of } \\
\text { the Estimate }\end{array}$} & \multicolumn{5}{|c|}{ Change Statistics } \\
\hline & & & & & $\begin{array}{l}\text { R Square } \\
\text { Change }\end{array}$ & $\begin{array}{c}\text { F } \\
\text { Change } \\
\end{array}$ & df1 & df 2 & $\begin{array}{c}\text { Sig. F } \\
\text { Change }\end{array}$ \\
\hline 1 & $.002^{\mathrm{a}}$ & .000 & -.016 & .920 & .000 & .000 & 2 & 124 & 1.000 \\
\hline
\end{tabular}

4.3.1 Model summary

a. Predictors: (Constant), LABOR MARKET, PUBLIC FINANCE

b. Dependent Variable: REAL_GDP

The study used the coefficient of multiple determinations to evaluate the model fit which is the adjusted Rsquared. Therefore, the adjusted R-squared was -0.016 , which states that $-1.6 \%$ of the variation of the dependent variables was explained by the independent variables. Meaning that Labor Market and Public Finance accounted for $-1.6 \%$ of the variations in the Real GDP of Ghana while $-98.4 \%$ was explained by others. 
Table 4: Analysis of the variance

\begin{tabular}{|l|l|r|r|r|r|r|}
\hline \multicolumn{7}{|c|}{ ANOVA $^{\mathbf{a}}$} \\
\hline \multirow{3}{*}{ Model } & Sum of Squares & \multicolumn{1}{c|}{$d f$} & Mean Square & \multicolumn{1}{c|}{ F } & Sig. \\
\hline \multirow{3}{*}{1} & Regression & .000 & 2 & .000 & .000 & $1.000^{\mathrm{b}}$ \\
\cline { 2 - 8 } & Residual & 104.929 & 124 & .846 & & \\
\cline { 2 - 8 } & Total & 104.929 & 126 & & & \\
\hline
\end{tabular}

a. Dependent Variable: REAL_GDP

b. Predictors: (Constant), LABOR_MARKET, PUBLIC_FINANCE

The table above shows the analysis of the variance (ANOVA). The results indicated that Labor Market and Public finance had no significant relationship with Real GDP. This was proved by the p-value of 1.000 , which is greater than the level of significance 0.05 . This shows that the independent variables were not significant in predicting the Real GDP of Ghana.

Table 5: Coefficients

\begin{tabular}{|c|c|c|c|c|c|c|}
\hline \multicolumn{7}{|c|}{ Coefficients } \\
\hline & & \multicolumn{2}{|c|}{ Unstandardized Coefficients } & \multirow{2}{*}{$\begin{array}{c}\text { Standardized } \\
\text { Coefficients } \\
\text { Beta }\end{array}$} & \multirow[b]{2}{*}{$\mathrm{t}$} & \multirow[b]{2}{*}{ Sig. } \\
\hline \multicolumn{2}{|c|}{ Model } & B & Std. Error & & & \\
\hline \multirow[t]{3}{*}{1} & (Constant) & 2.025 & .599 & & 3.380 & .001 \\
\hline & LABOR_MARKET & .000 & .028 & .001 & .010 & .992 \\
\hline & PUBLIC_FINANCE & -.001 & .059 & -.002 & -.022 & .983 \\
\hline
\end{tabular}

a. Dependent Variable: REAL_GDP

The representation above shows the coefficients of the regression. According to the SPSS generated output presentation given above, the equation is as follows;

\section{$Y=\beta_{0}+\beta_{1} X_{1}+\beta_{2} X_{2}$ therefore:}

$\mathrm{Y}=\mathbf{2 . 0 2 5}+\mathbf{0 . 0 0 0 L B}-\mathbf{0 . 0 0 1 P F}$

Where: $Y=$ Real GDP, $L B=$ Labor Market, $P F=$ Public Finance

The results indicated that when all factors are held constant Real GDP increases by 2.025 units. The labor market had 0.000units and Public Finance had -0.001 . However, when all factors are held constant as shown by the p-values the predictor variables Labor Market and Public Finance were not significant predictors of Real GDP. Therefore, to complete the study, a 5\% level of significance was used for the analysis. Hence, results show that Labor Market $(p=0.992)$ and Public Finance $(p=0.983)$ were not statistically significant in predicting the Real GDP of Ghana as the $p$ values were greater than the level of significance 0.05 .

We, therefore, reject the two null hypotheses as there was no positive relationship between the independent variables (Labor Market and Public Finance and the dependent variable Real GDP. This implies that Nigerian immigrants do not contribute to the Real GDP of Ghana.

\subsection{SUMMARY, CONCLUSION AND RECOMMENDATIONS}

\subsection{Summary}

The summary of the findings is guided by the objectives to analyze the impact of Nigerian Immigrants on the Economy of Ghana using statistical methods and models. It is on this premise, the study concludes that persons between the age group of 26- 35 are the most active in the immigration process. The study also showed that the number of males outnumbered that of the females. This result is not surprising because other authors had the same findings. Although a good number of respondents agreed Nigerian immigrants were more employed than Ghanaians were, the majority also disagreed when asked if Nigerian immigrants earned more wages than Ghanaians did. The result revealed Nigerian immigrants on arrival get employed in a short time as a quick means to cater for themselves but the meager wages they receive push them into the trade in the long run. Also, the study revealed Nigerian immigrants were not many in Industries. This result was very similar to other studies positing that Nigerian Immigrants were more likely to create their businesses or go into trading. Very key to the study was to investigate if Nigerian immigrants paid taxes or not. The majority of responses were negative hence their contribution to the real GDP of Ghana is insignificant. It is also imperative to note that Nigerian immigrant contribution to the economy of Ghana on an inclusive scale cannot be underemphasized yet statistically null, as there was no positive relationship between the independent variables Labor Market and Public Finance and the dependent variable Real GDP.

\subsection{Conclusion}

This paper contributes to the growing literature on the economic effects of immigration on host economies. In this study, the impact of Nigerian immigrants on Ghana's economy was analyzed; it focused strongly on their contribution to the labor market, public finance, and real GDP, using statistical analysis and models. This paper 
also highlights the need for more statistical studies, as well as large-scale surveys on the contribution of Nigerian immigrants to the economy of Ghana. Generally, the entry of immigrants is associated with a lower employment rate for native-born workers, yet in the case of Nigerian immigrants, they create their businesses hence unemployment rate is not affected. They even tend to engage some Ghanaians in their trade and businesses. This in a long run is a good development to Ghana as it contributes to a decrease in unemployment rates. In addition, as indicated in the study, Nigerian immigrants most likely do not pay corporate taxes. Valued added taxes are most definitely the taxes paid by Nigerian immigrants. More so, no detailed information is available on the actual contribution of immigrants to social security or the payment of taxes concerning international trade. This indicates that their contribution to public finance and real GDP is rather insignificant.

\subsection{Recommendations}

The study recommends the following based on the research:

- Nigerian immigrants who are into trade and own businesses should be encouraged and also, create financial facilities to assist them with capital on startups. This will go a long way to ease down the competition with native-born on limited jobs.

- Responsible organizations on Business registrations in Ghana should make sure Nigerian businesses are registered as well as pay the right amount of taxes to the government of Ghana.

- It is possible Nigerian migration to Ghana would increase in volume, thanks to the political stability and historical connection as well as the similarity in culture between the two countries (Antwi Bosiakoh, 2009) hence Ghana should strengthen government agencies dealing with immigration to pull out the positive effects that come with immigration in the future.

- More funding by the government should go into large level research on Nigerian immigrants to dig out data that will improve Ghana's understanding of immigration dynamics thus assisting in Ghana's national development planning.

\section{References}

Adamson, F. B. (2006). Crossing borders: international migration and national security. International Security, 31(1), 165-199.

Adepoju, A., \& van der Wiel, A. (2010). Seeking Greener Pastures Abroad - A Migration Profile of Nigeria, Ibadan: Safari Books Ltd

Adu, F., J. Ohene-Manu and A. Ishmael (2014), "Government Expenditures and Economic Growth in Ghana", International Journal of Economics and Empirical Research, Vol.2/5, pp.180-190.

Anarfi, J., Kwankye, S., Ababio, O. M., \& Tiemoko, R. (2003). Migration from and to Ghana: A background paper. University of Sussex: DRC on Migration, Globalisation, and Poverty.

Antwi Bosiakoh, T. (2009). Understanding Migration Motivations in West Africa: The Case of Nigerians in Accra, Ghana. Legon Journal of Sociology, 3(2), (Dec., 2006- June, 2009), 93-112.

Awumbila, M., Alhassan, O., Badasu, D., Bosiakoh, T. A., \& Dankyi, E. K. (2011). Socio-cultural dimensions of migration in Ghana Technical Paper Series No.3. University of Ghana

Beals, R. E., \& Menezes, C. F. (1970). Migrant labour and agricultural output in Ghana. Oxford Economic Papers, 22(1), 109-127.

Bryman, A. (2007). Barriers to integrating quantitative and qualitative research. Journal of mixed methods research, $1(1), 8-22$.

Card, D. (2005): "Is the new immigration really so bad?" The Economic Journal, 115, 300-323.

Chiswick, B. R. and P. W. Miller (1995): “The endogeneity between language and earnings: international analysis,' Journal of Labor Economics, 13, 246-288.

Friedberg, R. M., \& Hunt, J. (1995). The Impact of Immigrations on Host Country Wages,Employment and Growth. The journal of Economic Perspectives, 9(2), (Spring, 19995), 23-44.

Ghana Statistical Service (GSS) (2013). 2010 Population and Housing Census: National Report, GSS, Accra, Ghana. 277-79www.ghanadistrict.com

Kerr, S. P., \& Kerr, W. R. (2011). Economic impacts of immigration: A survey(No. w16736). National Bureau of Economic Research.

OECD (2013). "Migration and Employment", in OECD Factbook 2013: Economic, Environmental and Social. Statistics, OECD Publishing, Paris. DOI: http://dx.doi.org/10.1787/factbook-2013-8-en

OECD/ILO (2018), How Immigrants Contribute to Ghana's Economy, OECD Publishing, Paris. http://dx.doi.org/10.1787/9789264302037-en

Ottaviano, G. I. P. and G. Peri (2005): "Rethinking the gains from immigration: theory and evidence from the U.S." NBER Working Paper No. 11672.

Peri, G. (2007): "Immigrants' complementarities and native wages: evidence from California," NBER Working Paper No. 12956. 